\title{
Original
}

\section{Specific ICT training of older Brazilian workers}

\author{
Taiuani Marquine Raymundo $\mathrm{PhD}^{\mathrm{a}, *}$ \\ Carla da Silva Santana $\mathrm{PhD}^{\mathrm{b}}$
}

\begin{abstract}
a Occupational Therapy Department of the Federal University of Parana, Curitiba-Parana, Brazil; ${ }^{b}$ Health Science Department of the Ribeirao Preto Medical School, University of Sao Paulo, Ribeirao Preto-Sao Paulo, Brazil; *Corresponding author: taiuani@ufpr.br
\end{abstract}

\begin{abstract}
T.M. Raymundo, C. da Silva Santana. Specific ICT training of older Brazilian workers. Gerontechnology 2019;18(3):168-179; https://doi.org/10.4017/gt.2019.18.3.004.00 Background Technological advance and the mass insertion of technological equipment and information and communication technologies in the workplace require that workers, especially the older ones, adapt to these changes and deal with difficulties arising from their use. Research aim Analyze and compare the effect and impact of training on the use of technological devices and information and communication technologies in the participants' work performance. Methods Quantitative, descriptive, experimental and longitudinal study, composed by: pre-training, training, post-training and follow-up phases. A socioeconomic questionnaire, an interview about the technological devices and information and communication technologies used in the work environment, difficulties and strategies and self-assessment scales of training impact at work were used. Data were analyzed through descriptive statistics, Fisher's exact test, logistic regression and McNemar test. Results The mean age was 63.3 years older among the participated 30 workers with 15 men and 15 women. The approach adopted for training was practice centered on the client, in a simple and low complexity way. The positive effect of the training can be observed in the significative reduction of difficulties throughout its phases as well as in the analysis of its the impact. Gender, age, income and years of study showed a significative correlation with the degree of difficulty. The importance of continuing training in the lives of older workers became clear in follow up phase, since some of them presented an increase in difficulty three months after the end of the training. Conclusion The results of this study indicate the potential of a training program carried out a simple, low complexity and client centered approach. Understanding of how individuals deal with the new technologies, the challenges they impose and the variables that influence their use, are the basis for the development of successful training programs.
\end{abstract}

Keywords: aging, work, workplace, technology, training

\section{INTRODUCTION}

As a consequence of the aging of the population around the world, societies are currently dealing with the aging of the economically active population (EAP), as a result of the declining inflow of young people and the fact that workers are staying longer in the labor market (Camarano, Kanso, \& Fernandes, 2013).

A projection on growth rates for age groups between the period of 2010 to 2050 indicated that the group of young people aged between 15 and 29 years old may present negative growth rates, the segment aged between 30 and 59 years may present growth, however in a progressively smaller rate, and from 2045 only the group of older adults may have a positive growth rate (Camarano, 2014). Consequently, the federal government has been presenting measures and changes in social security over the years, which have led workers to stay longer in the labor mar- ket than previously expected.

Social trends indicate that a greater number of older workers will become a part of the Brazilian labor market every year, thus strategies to maximize productivity, health, safety, and the wellbeing of these workers will be necessary. Lack of appropriate planning in the near future may result in a shortage of labor and a shortage of skills (Alpass, \& Mortimer, 2007; Czaja, Sharit, Charness, \& Schmidt, 2015).

Changes in the $21^{\text {st }}$ century work environment have created new requirements for knowledge, skill, and capacity for workers. Technological innovations have led to continuous and rapid changes in the workplace. Currently, most workers use some kind of technology at work such as desktop computers and laptops, smartphones, tablets and multifunction devices. Such changes involve concerns about the ability of older work- 
ers to adapt to these changes, because most of the technologies available today were not part of the environment of workers aged 50 or over when they received training for their careers. In addition, technological changes, especially concerning the expansion of the computer science, optimized the time of the information speed and (geographic) space, resulting in direct impacts in the relational dimensions of the individuals and of work (Czaja, Sharit, Charness, \& Schmidt, 2015; Alley, \& Crimmins, 2007; Lee, Czaja, \& Sharit, 2009).

The most known factors that make it difficult for the population to adapt to the insertion of technologies in their work activities are the natural declines in physical and cognitive abilities, reluctance to learn to use both technological devices (TD) and information and communication technologies (ICT), and social factors such as cultural and linguistic differences (Lee, Czaja, \& Sharit, 2009; Umemuro, 2002).

The labor market has sought qualified people and has marginalized individuals who do not master technologies. Therefore, workers will have to continually adapt to changes arising from globalization and advances in information technology. The reduction of differences in professional skills, especially in relation to the rapid technological advances, can be achieved through the provision of lifelong learning and training programs (Czaja, Sharit, Charness, \& Schmidt, 2015; Souza, \& Melo, 2017). A training program may enable older workers to improve their skills and continue to perform their duties satisfactorily (Ilmarinen, \& Ilmarinen, 2015).

Training modalities and techniques are also recommended to improve the performance of young adults as well as older people. The exception concerns the improvement of the development of practical activities (hands-on) in relation to conceptual trainings (theoretical) of older adults (Leppel, Brucker, \& Cochran, 2012). Thus, it is essential to provide access to training and to ensure that the training program is appropriate to the needs and preferences of older adults so that there is "success in learning" (Charness, \& Czaja, 2006).

In addition to the inherent challenge of technologies, prejudices, myths, and stereotypes permeate the organizational culture of older workers (Beier, 2015). Among them, we can highlight the belief that older workers are difficult to train, have a lower capacity to learn new tasks, especially those that involve the use of technologies, have a lower labor and productive capacity and present a decrease in physical abilities (Czaja, Sharit, Charness, \& Schmidt, 2015; Sharit, Czaja, Hernandez, \& Nair, 2009).
Contrary to myths, studies suggest that older people are able to learn new skills, including those involving technological equipment and information and communication technologies, however, they are generally slower to acquire skills that involve technological devices than younger adults (Charness, \& Czaja, 2006; Beier, \& Ackerman, 2005; Nicoll, 2003; Tomporowski, 2003).

In that regard, this study is justified by the need to answer some questions that seem central to understand the impact caused by the insertion of technologies in the work environment in Brazil. It must be considered that work is one of the main areas of human occupation, it is not only necessary but also a key element in social integration, considering that much of the time and energy of the individuals is invested in it. It is through work, in the sense of contribution and public utility, that individuals see the possibility of citizenship and inclusion in society (Nardi, 2006). Together with the fact that workers are staying longer in the labor market, we must consider all the changes that have occurred in this context. Technological advance and the mass insertion of technological equipment and information and communication technologies in the workplace require that workers, especially the older ones, adapt to these changes and deal with difficulties arising from their use. Thus, this study aimed to analyze the impact of a training on the difficulties and in the use of TD and ICT in the participants' work performance immediately after its conclusion, and three months later.

\section{Method}

This is a qualitative and quantitative, descriptive, interventional, longitudinal, and prospective study consists of four phases: pre-training, training, post-training, and follow-up. The project was approved by the Committee of Ethics in Research, number: 811.505, fulfilling the ethical principles of researches involving human beings.

The inclusion criteria of the study were: workers aged 50 years or older, who had difficulty using TD or ICT, of both sexes, of any marital status, any socioeconomic class, minimum schooling of four years of study, without reported cognitive deficits (by Mini Mental State Examination (MMSE), without neuromotor disabilities, and with without vision problems. Exclusion criteria were: individuals less than 50 years of age who did not engage in work activities, did not use TD and ICT at work, had no difficulties in using them, were illiterate, had neuromotor disabilities, and had uncorrected (deficient) sensory deficits. visual and auditory) or cognitive deficits reported.

Sampling was selected by means of a non-probabilistic technique called intentional sampling 
for convenience. To make the sample homogeneous, six strata were created (stratum 1: men aged 50 to 59 years; stratum 2: women aged 50 to 59 years, stratum 3: men aged 60 to 69 years, stratum 4: women aged 60 to 69 years, stratum 5: men aged 70 to 79 years, stratum 6: women aged 70 to 79 years), which helped recruit subjects. The strata were balanced and composed of five participants each, which totaled a sample of 30 participants at the end of the study.

The participants were recruited by invitation, through a poster at digital media (social networks and electronic mail) of the Federal University of Parana - Brazil, as well as of the city of Curitiba and the metropolitan region. The contact between the interested parties and the researcher was made through email or telephone available in the poster. The trainings were carried out at Federal University of Parana and at the participants' own workplace when necessary. The following instruments were applied to those who accepted the invitation.

\section{Pre-training phase}

To meet the selection criteria, the participants were submitted to the Mini Mental State Examination (MMSE) (Folstein, Folstein, \& McHugh, 1975) with a passing grade of illiterates $=13$ points; $1-7$ years of education $=18$ points; 8 years of education or more $=26$ points, as proposed by Bertolucci and collaborators (Bertolucci, Brucki, Campacci, Juliano, 1994).

The selected participants answered a socioeconomic questionnaire with information about age, marital status, occupation, education, income and specific questions about work activities such as the position held, the work regime, weekly workload and working time, in previous and current employment.

After that, the participants answered the questionnaire about TD and ICT used in the work environment, which was developed by the author of this study based on the questionnaire about the experience with computers and technologies developed by Center for Research and Education on Aging and Technology Enhancement -CREATE (Czaja et al., 2006). This instrument was divided by TD and ICT and aimed to identify which TD and ICT the participants used at work, if they had already received training to use them, whether or not they had difficulties in using it and, if so, what grade of its difficulty (none, few, many) and what specific difficulties. The following TD and ICT were addressed in the questionnaire: smartphone; fax machine; computer; copier/scanner; Internet; email; printer; card machine (credit/debit/voucher); ATM; barcode reader; telephone switchboard; tablet; re- cording and playback devices such as CD, DVD, flash drive, multimedia projector and others that can be choosed by the participants. When the participant reported using the email at work, for example, after indicating that he or she received training for use and the degree of difficulty in using it, he should choose his specific difficulty in using this ICT (send an e-mail to a person or a set of people, respond to a person or a set of person, forward to a person or a set of people, attach files, create and manage folders and others).

\section{Training phase}

The approach used in the development of training was the client-centered practice (CCP), which can be defined as an approach that recognizes the autonomy of the subject, his/her need to choose alone what he/she needs and wants to learn, and his/her recognition of which difficulties affect their performance, in the case of this study, in their work. This approach aims to provide subjects services that are more appropriate to the particular context in which they live. It is believed that as long as the information provided by participants in training programs is valued and respected, there will be greater involvement of the subject (American Occupational Therapy Association, 2014; Law, Baptiste, \& Mills, 1995; Sumsion, \& Smyth, 2001; Vaz, Jubilini, \& Queiroz, 2017).

Thus, the trainings were designed individually, and the duration, frequency and number of training sessions were defined according to the needs of each participant related at the questionnaire about TD and ICT used in the work environment. In addition, the structuring, planning and development of the training were based on (Czaja, \& Sharit, 2012):

- Previous knowledge about TD or ICT;

- Aspects related to the aging process (cognitive abilities, physical and sensory functions, for example);

- Adequacy of the environment to the needs of the participants;

- Differentiated pedagogical practice according to the needs and pace of learning of each participant;

- Logical sequence of contents (smaller for greater complexity);

- Practical exercises for content fixation and generalization of learning.

The instructional materials were built throughout each session, individually, with letters of adequate size and font (arial 14pt), sentence spacing, step by step functions, real illustrations, with simple language and reduction of technical terms.

\section{Post-training and follow-up phase}

At the end of the training and three months after that, the participants answered again a question- 
naire about TD and ICT used in the work environment, and a self-assessment scale of the impact of training in the workplace - measure in amplitude of Abbad (1999). The "self-assessment scale of the impact of training in the workplace" is composed of 12 items and the answers are given according to a 5-point Likert scale (Pilati, \& Abbad, 2005). For scoring, a value is assigned to each answer (I totally agree $=1$, agree $=2$, neutral $=3$, disagree $=4$, totally disagree $=5$ ) . For the analysis of the impact for each participant and for the sample, the sum of the scores attributed by each participant to each item is calculated and then the mean $(\mathrm{M})$ and the standard deviation (SD) are also calculated. For those participants who presented mean equal to or lower than 2.99 (1 to 2.99) it was considered that there was an impact of the training and for participants who presented mean above 3 ( 3 to 5 ) there was no impact. The overall impact of training is calculated from the overall mean of the responses of all participants divided by the total items of the instrument (Abbad, Pilati, Borges-Andrade, \& Sallorenzo, 2009).

\section{Data analysis}

The data were analyzed through the descriptive statistics method, and to verify the training effect in relation to the qualitative variables, that is, the comparison of the participants' responses between the phases, the McNemar test was performed. To analyze the association between variables, Fisher's exact test and logistic regression were used. The SAS 9.2 software was used for the analyses, and a significance level of $5 \%$ was used for all comparisons.

\section{Results \\ Pre-training phase}

Thirty workers, 15 men and 15 women, aged between 50 and 75 years with a mean age of 63.3 participated in the study. Of the participants, $56.6 \%$ are married, $53.3 \%$ have more than 15 years of formal education, and $70.0 \%$ have a monthly income equal to or greater than $\mathrm{R} \$$ 5,201.00 (approximately 1,287 Euros).

The participants also reported several previous and current occupations (higher education teacher, occupational therapist, journalist, business administrator, agronomist, typist, library assistant, finance director, foreign language teacher, among others). Out of these, $26.7 \%$ reported having the same occupation until the present, regardless of whether they changed their place of work and whether they were retired or not, $36.7 \%$ changed occupations, however, they still perform their activities in the same area of knowledge of their previous work, and $26.7 \%$ reported changes both in their current work activities and in their area of knowledge, when compared to their previous oc- cupations. Finally, $10.0 \%$ of the participants still perform the same function, but they were hired as "senior employees" because they are retired. In relation to the current occupation, $53.3 \%$ work full time and $13.3 \%$ work part time, $16.7 \%$ are self-employed, $10.0 \%$ are volunteers and $6.7 \%$ work according to demand.

In this phase, the influence of socioeconomic characteristics on the degree of difficulty of the participants was analyzed. At the level of significance adopted, the gender variable showed a positive correlation with the degree of difficulty in the use of the printer ( $p$-value $=0.03$ ), and after logistic regression, different from expected, men presented $48.6 \%$ more chance in presenting difficulty in using this equipment than women. The variable age presented a positive correlation with the degree of difficulty in using the computer $(p$-value $=0.03)$. The years of study presented a positive correlation with the degree of difficulty in the use of the cell phone $(p$-value $=0.03)$ and in the use of the computer ( $p$-value $<0.01)$, and the income variable presented a positive correlation with the degree of difficulty in using the computer $(p$-value $=0.03)$ (Table 1).

\section{Training phase}

Regarding the use of technologies in the work environment, the most used TD and ICT were the common smartphone $(73.3 \%)$, computer $(100 \%)$, copier $(83.3 \%)$, internet $(96.7 \%)$, e-mail $(96.7 \%)$, printer $(90.0 \%)$ and recording and playback devices (CD, DVD and flash drive) (80.0\%). Among the participants who reported using TD and ICT, despite the significant use, only a few reported having received training to use them.

When asked about the degree of difficulty (none, some or much) in the use of TD and ICT, greater difficulties were reported in computer use $(96.6 \%)$, followed by the common smartphone and smartphone (81.8\%), (75.0\%), e-mail (69.0\%), GPS (100.0\%) and Bluetooth (100.0\%).

Due to the variation of the difficulties presented by the participants and considering the methodology adopted in the training, the number and duration of the sessions were different for each participant. Practical classes were held, ranging from 45 to 120 minutes, between one and two times a week, and the number of training sessions ranged from one to 19 (frame 1). The variation was often related to greater difficulty in retaining information, lower learning pace, little time available for training, because this often happens in the workplace and the need to review content at the beginning of each new session, which eventually increased the duration of these. 
Table 1. Association between degree of difficulty and gender, age group, years of study and income

\begin{tabular}{lccc}
\hline $\begin{array}{l}\text { Printer } \\
\text { Difficulty level }\end{array}$ & $\begin{array}{c}\text { Gender } \\
(\mathrm{N}=14)^{\mathrm{a}}\end{array}$ & $\begin{array}{c}\text { Male } \\
(\mathrm{N}=13)^{\mathrm{a}}\end{array}$ & $\begin{array}{c}\text { Total } \\
(\mathrm{N}=27)^{\mathrm{b}}\end{array}$ \\
\hline & 78.6 & 38.5 & 59.3 \\
I don't have & 14.3 & 61.5 & 37.0 \\
I have some & 7.1 & 0.0 & 3.7 \\
I have a lot & 100.0 & 100.0 & 100.0 \\
Total & & & \\
p-value=0.03 & & & \\
\hline
\end{tabular}

\begin{tabular}{|c|c|c|c|c|}
\hline \multirow[b]{2}{*}{$\begin{array}{l}\text { Computer } \\
\text { Difficulty level }\end{array}$} & \multicolumn{4}{|c|}{ Age group } \\
\hline & $\begin{array}{l}\mathbf{5 0} \text { a } 59 \\
(\mathrm{~N}=10)^{\mathrm{a}}\end{array}$ & $\begin{array}{l}60 \text { a } 69 \\
(\mathrm{~N}=10)^{\mathrm{a}}\end{array}$ & $\begin{array}{l}70 \text { a } 79 \\
(\mathrm{~N}=10)^{\mathrm{a}}\end{array}$ & $\begin{array}{c}\text { Total } \\
(\mathrm{N}=30)^{b}\end{array}$ \\
\hline I don't have & 0.0 & 10.0 & 0.0 & 3.3 \\
\hline I have some & 100.0 & 70.0 & 50.0 & 73.3 \\
\hline I have a lot & 0.0 & 20.0 & 50.0 & 23.3 \\
\hline Total & 100.0 & 100.0 & 100.0 & 100.0 \\
\hline p-value $=0.03$ & & & & \\
\hline
\end{tabular}

\begin{tabular}{lccccc}
\hline $\begin{array}{l}\text { Smartphone } \\
\text { Difficulty level }\end{array}$ & $\begin{array}{c}\text { De 4 a 8 } \\
(\mathrm{N}=0)^{\mathrm{a}}\end{array}$ & $\begin{array}{c}\text { De 8 a 11 } \\
(\mathrm{N}=2)^{\mathrm{a}}\end{array}$ & $\begin{array}{c}\text { De 11 a 15 } \\
(\mathrm{N}=5)^{\mathrm{a}}\end{array}$ & $\begin{array}{c}\text { More than 15 } \\
(\mathrm{N}=15)^{\mathrm{a}}\end{array}$ & $\begin{array}{c}\text { Total } \\
(\mathrm{N}=22)^{\mathrm{b}}\end{array}$ \\
\hline I don't have & 0.0 & 50.0 & 0.0 & 20.0 & 18.2 \\
I have some & 0.0 & 50.0 & 20.0 & 66.7 & 54.5 \\
I have a lot & 0.0 & 0.0 & 80.0 & 13.3 & 27.3 \\
Total & 0.0 & 100.0 & 10.0 & 100.0 & 100.0 \\
p-value=0.03 & & & & & \\
\hline
\end{tabular}

\begin{tabular}{lccccc}
\hline $\begin{array}{l}\text { Computer } \\
\text { Difficulty level }\end{array}$ & $\begin{array}{c}\text { De 4 a 8 } \\
(\mathrm{N}=1)^{\mathrm{a}}\end{array}$ & $\begin{array}{c}\text { De 8 a 11 } \\
(\mathrm{N}=7)^{\mathrm{a}}\end{array}$ & $\begin{array}{c}\text { De 11 a 15 } \\
(\mathrm{N}=6)^{\mathrm{a}}\end{array}$ & $\begin{array}{c}\text { More than 15 } \\
(\mathrm{N}=16)^{\mathrm{a}}\end{array}$ & $\begin{array}{c}\text { Total } \\
(\mathrm{N}=30)^{\mathrm{b}}\end{array}$ \\
\hline I don't have & 0.0 & 0.0 & 16.7 & 0.0 & 3.3 \\
I have some & 100.0 & 71.4 & 16.7 & 93.7 & 73.3 \\
I have a lot & 0.0 & 28.6 & 66.6 & 6.3 & 23.3 \\
Total & 100.0 & 100.0 & 100.0 & 100.0 & 100.0 \\
p-value $<0.01$ & & & & & \\
\hline
\end{tabular}

\begin{tabular}{lccccc}
\hline Computer & \multicolumn{5}{c}{ Income (in Brazilian Real) } \\
\cline { 2 - 6 } Difficulty level & $\begin{array}{c}\mathbf{1 3 0 1} \text { to } \\
\mathbf{2 6 0 0} \\
(\mathrm{N}=1)^{\mathrm{a}}\end{array}$ & $\begin{array}{c}\mathbf{2 6 0 1} \text { to } \\
\mathbf{3 9 0 0} \\
(\mathrm{N}=3)^{\mathrm{a}}\end{array}$ & $\begin{array}{c}\mathbf{3 9 0 1} \text { to } \\
\mathbf{5 2 0 0} \\
(\mathrm{N}=5)^{\mathrm{a}}\end{array}$ & $\begin{array}{c}\text { More than } \\
\mathbf{5 2 0 1} \\
(\mathrm{N}=21)^{\mathrm{a}}\end{array}$ & $\begin{array}{c}\text { Total } \\
(\mathrm{N}=30)^{\mathrm{b}}\end{array}$ \\
\hline I don't have & 0.0 & 33.3 & 0.0 & 0.0 & 3.3 \\
I have some & 100.0 & 0.0 & 80.0 & 80.9 & 73.3 \\
I have a lot & 0.0 & 66.7 & 20.0 & 19.1 & 23.3 \\
Total & 100.0 & 100.0 & 100.0 & 100.0 & 100.0 \\
p-value=0.03 & & & & & \\
\hline
\end{tabular}

\footnotetext{
a Number of participants who reported using TD or ICT at work.

b Percentage of participants reporting any, some or very difficulties in using this TD or ICT (the number of participants who reported using ICT at work was considered to be $100 \%$ ).
} 


\section{Post-training and follow-up phase: analysis of difficulties}

According to the participants' responses after training, the TD and ICT most used in the workplace were the same reported previously. After training, the TD and ICT which the participants reported greater degree difficulty were smartphone $(55.0 \%)$, computer $(56.6 \%)$, tablet $(60.0 \%)$, GPS (100.0\%), and Bluetooth (100.0\%).

After three months of the end of the training, the TD and ICT most used in the workplace remained the same as the ones in previous phases. Regarding the degree of difficulty, greater difficulties were presented in the use of TD and ICT, such as smartphone $(44.5 \%)$, computer $(66.7 \%)$, copier (40.0\%), GPS 0\%) and Bluetooth (100.0\%).

In the comparison between the pre and posttraining phases, after applying the McNemar test, an important effect of the training performed (greater reduction in the degree of difficulty) was observed.

A significant reduction in the degree of difficulty was observed in the use of the following TD and ICT: smartphone $(63.2 \%$ - p-value $<0.01)$; computer $(60.0 \%$ - $p$-value $<0.01)$; recording and playback devices $(53.0 \%$ - p-value $=0.04)$; copier $(45.0 \%$ - p-value $=0.03)$; e-mail $(43.4 \%$ $\mathrm{p}$-value $=0.02)$; and internet $(39.3 \%-\mathrm{p}$-value $=$ 0.04) (Table 2). The other TD and ICT also presented a decrease in the degree of difficulty, although the training effect for them was not significant (Table 2).

When comparing the pre-training and follow-up phases, significant reduction in the degree of difficulty was observed in the use of the following TD and ICT: computer $(46.7 \%$ - p-value $<0.01)$; internet $(44.8 \%-p$-value $=0.02)$; and recording and playback devices $(53.0 \%-p$-value $=0.03)$ (Table 3). Same as the previously comparison, the other TD and ICT also presented a decrease in the level of difficulty but was not significant.

Therefore, the variation in the degree of difficulty presented by the participants between the post training and follow-up phases, was not possible to notice a significant effect of the training. In this comparison the percentages of difficulty reduction were lower than others presented previously, and greater difficulties were observed in the use of computer (20.0\% present more difficult), copier $(33.0 \%)$; printer $(21.7 \%)$; and e-mail $(21.4 \%)$. These results may be due to the fact that the participants did not apply what was taught during the training more frequently and/or to the emergence of new difficulties as a result of their crescent interest in using more TD and ICT functions.

\section{Post-training and follow-up phase - Impact analysis}

In relation to impact, considering the mean of all participants, the overall balance points to a positive impact of training in their workplace.

When considering the participants' individual responses, the training had a positive impact for the majority of the participants and, for one participant alone, it had no impact, although its mean (3.1) was close to the impact (2.99).

The statements of the scale, which a larger number of participants reported agreeing or fully agreeing with, after the training, were: "I often use what I have been taught during training in my current job"; "I take advantage of the opportunities I have to put what was taught during training into practice"; "The skills I learned during training led me to make fewer mistakes in my work concerning activities related to the training content"; "When I apply what I have learned in training, I do my work more quickly"; "The quality of my work improved in the activities directly related to the content of the training" and; "The training made me more receptive to changes in my work".

On the other hand, the statements which a larger number of participants reported disagreeing or totally disagreeing with were: "I remember well the contents taught in the training" and "The training also benefited my co-workers, who learned from me some new skills".

Thus, the improvement in participants' abilities resulting from the training can be noticed when the majority states that the skills they learned in training made them commit less mistakes, in their work (90\% post-training, 100\% follow-up); when reporting that in applying what they have learned in training, they do their work faster; and when they report that the quality of their work improved in relation to training content.

Regarding the maintenance of the impact of the training, the training continued to have effect in the work even after three months. As in the posttraining phase, in the follow-up phase, when analyzing the individual responses, it was possible to notice that the training did not have a positive impact for only one participant (different participants).

\section{Discussion}

Two major trends have driven Brazilian economic development: the demographic transition and the rapid evolution of technology. There is a noticeable increase in the number of older workers in the labor market, who have experienced many changes, whether in the organization of work, in their context or in the tasks to be carried out. With the technological evolution has been re- 
Table 2. Reduction in the degree of difficulty of the participants: Comparison between pre-training and post-training phases

\begin{tabular}{|c|c|c|c|c|}
\hline TD/ICT & I don't have & I have some & I have a lot & Total \\
\hline Smartphone (pre-training) & \multicolumn{4}{|c|}{ Smartphone (post-training) } \\
\hline I don't have & 10.5 & 0.0 & 0.0 & 10.5 \\
\hline I have some & 31.6 & 26.3 & 0.0 & 57.9 \\
\hline I have a lot & 0.0 & 31.6 & 0.0 & 31.6 \\
\hline Total & 42.1 & 57.9 & 0.0 & 100.0 \\
\hline \multicolumn{5}{|l|}{ p-value $<0.01$} \\
\hline Computer (pre-training) & \multicolumn{4}{|c|}{ Computer (post-training) } \\
\hline I don't have & 0.0 & 3.3 & 0 & 3.3 \\
\hline I have some & 36.7 & 33.3 & 3.3 & 73.3 \\
\hline I have a lot & 6.7 & 16.7 & 0.0 & 23.3 \\
\hline Total & 43.3 & 53.3 & 3.3 & 100.0 \\
\hline \multicolumn{5}{|l|}{$p$-value $<0.01$} \\
\hline Copier (pre-training) & \multicolumn{4}{|c|}{ Copier (post-training) } \\
\hline I don't have & 35.0 & 0.0 & 0.0 & 35.0 \\
\hline I have some & 45.0 & 20.0 & 0.0 & 65.0 \\
\hline I have a lot & 0.0 & 0.0 & 0.0 & 0.0 \\
\hline Total & 80.0 & 20.0 & 0.0 & 100.0 \\
\hline \multicolumn{5}{|l|}{$p$-value $=0.03$} \\
\hline Internet (pre-training) & \multicolumn{4}{|c|}{ Internet (post-training) } \\
\hline I don't have & 21.4 & 3.6 & 0.0 & 25.0 \\
\hline I have some & 35.7 & 32.1 & 0.0 & 67.9 \\
\hline I have a lot & 0.0 & 3.6 & 3.6 & 7.1 \\
\hline Total & 57.1 & 39.3 & 3.6 & 100.0 \\
\hline \multicolumn{5}{|l|}{$p$-value $=0.04$} \\
\hline E-mail (pre-training) & \multicolumn{4}{|c|}{ E-mail (post-training) } \\
\hline I don't have & 28.6 & 3.6 & 0.0 & 32.1 \\
\hline I have some & 39.3 & 21.4 & 0.0 & 60.7 \\
\hline I have a lot & 3.6 & 3.6 & 0.0 & 7.1 \\
\hline Total & 71.4 & 28.6 & 0.0 & 100.0 \\
\hline \multicolumn{5}{|l|}{$p$-value $=0.02$} \\
\hline $\begin{array}{l}\text { Recording and playback } \\
\text { devices (pre-training) }\end{array}$ & \multicolumn{4}{|c|}{$\begin{array}{c}\text { Recording and playback devices } \\
\text { (post-training) }\end{array}$} \\
\hline I don't have & 29.4 & 0.0 & 0.0 & 29.4 \\
\hline I have some & 47.1 & 17.7 & 0.0 & 64.7 \\
\hline I have a lot & 0 & 5.9 & 0.0 & 5.9 \\
\hline Total & 76.5 & 23.5 & 0.0 & 100.0 \\
\hline$p$-value $=0.04$ & & & & \\
\hline
\end{tabular}


Table 3. Reduction/Increase/Maintenance in the degree of difficulty of the participants in the use of the computer, internet and recording and playback devices: comparison between the pre-training and follow-up phases

\begin{tabular}{|c|c|c|c|c|}
\hline TD/ICT & I don't have & I have some & I have a lot & Total \\
\hline Computer (pre-training) & \multicolumn{4}{|c|}{ Computer (follow-up) } \\
\hline I don't have & 3.3 & 0.0 & 0.0 & 3.3 \\
\hline I have some & 23.3 & 50.0 & 0.0 & 73.3 \\
\hline I have a lot & 6.7 & 16.7 & 0.0 & 23.3 \\
\hline Total & 33.3 & 66.7 & 0.0 & 100.0 \\
\hline \multicolumn{5}{|l|}{$\mathrm{p}$-value $<0.01$} \\
\hline Internet (pre-training) & \multicolumn{4}{|c|}{ Internet (follow-up) } \\
\hline I don't have & 20.7 & 3.5 & 0.0 & 24.1 \\
\hline I have some & 37.9 & 31.0 & 0.0 & 69.0 \\
\hline I have a lot & 3.5 & 3.5 & 0.0 & 6.9 \\
\hline Total & 62.1 & 37.9 & 0.0 & 100.0 \\
\hline \multicolumn{5}{|l|}{$p$-value $=0.02$} \\
\hline $\begin{array}{l}\text { Recording and playback } \\
\text { devices (pre-training) }\end{array}$ & \multicolumn{4}{|c|}{$\begin{array}{l}\text { Recording and playback devices } \\
\text { (follow-up) }\end{array}$} \\
\hline I don't have & 29.4 & 0.0 & 0.0 & 29.4 \\
\hline I have some & 47.1 & 17.7 & 0.0 & 64.7 \\
\hline I have a lot & 0 & 5.9 & 0.0 & 5.9 \\
\hline Total & 76.5 & 23.5 & 0.0 & 100.0 \\
\hline$p$-value $=0.03$ & & & & \\
\hline
\end{tabular}

quired of the workers the domain of machines and electronic equipment (Czaja, Sharit, Charness, \& Schmidt, 2015; Lancman, Jardim, \& Barros, 2013; Sznelwar, Uchida, \& Lancman, 2011; Huber, \& Watson, 2014). On the other hand, such changes have not been accompanied by training programs, which often generate difficulties, challenges and insecurity for workers who have not had contact with these technological devices throughout their career.

The lack of professional knowledge and skills is considered to be one of the most important obstacles to the employment of older workers (Lee, Czaja, \& Sharit, 2009; Tuominen, \& Takala, 2006). These workers are often considered the most difficult part of the population to adapt to technological equipment and ICT and face challenges in trying to interact with them in their work environments. The difficulty is often due to both the incompatibility between technological skills and the technological requirements of available jobs and the reluctance to learn to use technological equipment and ICT, plus factors related to the aging process itself (Lee, Czaja, \& Sharit, 2009; Umemuro, 2002).

In this study, the difficulty in using TD and ICT showed a significant association in relation to gender, age and income. Regarding gender, women presented less difficulty in using the printer when compared to men, contrary to the majority of the studies that show that men are friendlier with technologies than women (Cai, Fan, \& Du, 2017). As for the age, in agreement with the literature, the advance of this one was associated to the increase in the difficulty in the use of the computer (Choi, \& Dinitto, 2013; Friemel, 2014). Higher income and more years of schooling were associated with lower degrees of difficulties in computer and smartphone use, which is in line with the literature findings. According to some studies (Ogata, 2012), higher levels of education are correlated with increased knowledge and experience related to TD and ICT and, income is positively associated with greater digital access, as well as more advanced digital skills (Ono, \& Zavodny, 2007; Van Deursen, \& Van Dijk, 2011).

Such difficulties and obsolescence of skills can be prevented through training programs. Aging is not a problem, and cannot be considered as such, because learning new skills is possible in any age group. Work training in conjunction with various other types of courses gives older workers opportunities to improve their skills, which enables them to adapt to changes and continue 
to perform their duties satisfactorily (Ilmarinen, \& Ilmarinen, 2015).

The trainings can consist of individual sessions, group sessions, workshops, online instructions, manual instructions, or informal training from a co-worker, family, friend, or a combination of all of these. Programs can vary in duration, frequency, session size, structure, and other factors such as protocols used for evaluation and reevaluation. Training can also be done at the pace of the participant or the trainer, or even a specific program (for online learning for example). It can occur in a variety of environments such as the workplace, the participant's house, in a classroom, community centers, or even at a distance. However, the characteristics and needs of those who receive the training should always be considered (Czaja, \& Sharit, 2012). Furthermore, the training objectives should always be aligned with those of work and they should consider the individual differences in TD and ICT learning. In addition, training objectives should always be aligned with work, should consider individual differences in TD and ICT learning and should be flexible and responsive to the skills and needs of each worker (Lee, Czaja, \& Sharit, 2009; Carmichael, \& Ercolani, 2014; Ravichandran, Cichyb, Powers, \& Kirby, 2015).

According to a study, which sought to analyze the employment and trainings received by older workers, these workers preferred that trainings happened in the workplace and that they were composed of practical activities rather than theoretical training in classrooms (Smith, Smith, \& Smith, 2010). They also indicated that they prefer trainings focused on specific tasks. Another study poited out that training, in the use of technologies, should provide a lot of time for the practice of the trained functions and a supportive environment, through the combination of classroom-based and individual approaches (Chiu et al., 2016). In a review study that sought to critically examine the current state of research on the use of systematic instructional design procedures to develop job-related training for older workers (Van Rooij, 2012). Focusing only on studies that contained a pre-test/post-test study project with reported effect sizes, the author found that small-group training or those that took into account each participant's learning pace were related to high levels of performance when compared to trainings performed in large groups and in a different pace than the worker's receiving the training. In addition, evidence indicates that older workers perform well in training, especially when they are guided considering the reality of each worker, age issues, their previous knowledge, skills, goals, attitudes, motivation, values and interests (Ilmarinen, \& Ilmarinen, 2015; Beier,
2015; Czaja, Sharit, 2012; Van Rooij, 2012).

Therefore, the training carried out in this study approached practically all the factors considered important for the accomplishment of training with older workers and, after analyzing the comparisons, the positive effect of the training can be observed in the reduction of difficulties throughout its phases as well as in the analysis of its the impact. The participants noticed that they performed their tasks faster, made fewer mistakes, which could be a predictor for the reduction of embarrassing situations, remembered what they learned in the training, experienced improvement in the quality of work, and realized that they can contribute to their workplace and to the relationships they experience in it (Ravichandran, Cichyb, Powers, \& Kirby, 2015). It is also worth mentioning that participants showed the ability to apply what they learned in training in their workplaces, which contributes to better experiences of workers, according to European Centre for the Development of Vocational Training (Laganà, Oliver, Ainsworth, \& Edwards, 2011).

The methodology used in the training had a simple, low-complexity and client-centered practice. It was concerned with the identification of issues that workers considered important, necessary and essential for them to remain in the labor market. This contributed to the positive outcomes presented in the study: reduction of difficulties in the use of technology and the impact of training. As in most of the trainings in this study, the literature also considered necessary, for older workers, the provision of a simple and individual training program, for technology learning, lasting several weeks (Van Rooij, 2012).

Contradicting myths and stereotypes, the participants of this study were able to learn, and after a training that respected their limits, time and interest, they overcame barriers such as misperception about their own capacities and abilities, lack of confidence and negative feelings. In addition, a meta-analysis and other studies (Ilmarinen, \& Ilmarinen, 2015; Czaja, \& Sharit, 2012; Ravichandran, Cichyb, Powers, \& Kirby, 2015; European Centre for the Development of Vocational Training, 2012), pointed out that the training significantly improves the performance and skills of older workers.

Training enables workers to acquire greater knowledge through learning, improve their social relations and quality of work, which contributes to greater motivation at work (Beier, 2015; Laganà, Oliver, Ainsworth, \& Edwards, 2011). According to studies (Callahan, Kiker, \& Cross, 2003; Bal, Kooij, \& Rousseau, 2015), companies, labor organizations and employers need to un- 
derstand how to manage older workers and ensure adequate occupational well-being by motivating them to work and providing and ensuring their participation in training programs. Training, when properly implemented and adapted, produces remarkable gains for both workers and their employers (Finkelstein, Truxillo, Fracarolli, \& Kanfer, 2015; Noe, 2010).

Even with good indicators of reduction of the difficulty and positive impact of the training, it was possible to notice that over the time some participants presented an increase in the degree of difficulty. It should be noted that the increase in some participants' degree of difficulty may be related to the fact that they did not apply what was taught during training, which may serve as an alert to aspects such as frequency of task repetition and duration of training. Regarding the memory of learned skills, older adults do not usually have difficulty remembering how tasks are performed once they have received sufficient amounts of practice (Czaja, \& Sharit, 2012). However, the differences presented among the participants of this study, especially in the follow-up phase, may be a consequence of short-term interindividual variability, in which the performance of individuals can vary due to factors such as fatigue, distractions, lapses of attention among others (Czaja, \& Sharit, 2012). Retraining of tasks may be needed for the contents to be "well-learned" and to minimize possible cases of "non-learning", and such actions may be important for strengthening the benefits achieved in the training after its completion (Czaja, \& Sharit, 2012).

The results of this study suggest the importance of continuous learning. The $21^{\text {st }}$ century, with its enormous changes especially concerning technology, is considered to be the age of lifelong learning, and in a society where life expectancy grows at alarming levels, lifelong learning ceases to be a slogan and becomes a way of life (Turek, \& Perek-Bialas, 2013). The obsolescence of skills, driven by the technological changes that occur in the workplace, reinforces the need for such learning (Chang, \& Lin, 2011).

Lifelong learning enables older workers to follow technological advances and keep themselves up to date, facing technology-related difficulties in all contexts they may live in, and it is also an important factor for both healthy aging and long life at work (Boulton-Lewis, 2010; Ilmarinen, \& Ilmarinen, 2015; Allen, \& De Grip, 2012).
This is a key element to compensate for the decline in qualifications of older workers as a result of constant technological advances and to increase productivity (Organization for economic co-operation and development, 2006). In addition, lifelong learning and staying longer in the labor market should be greater than the depreciation of older workers and the retirement at ages still productive (Kooij, \& Zacher, 2016).

\section{Conclusion}

Considering the aging of the population, changes in the social security sector, which lead older adults and elderly to stay longer in the labor market, and the presence and use of technologies in labor environments, the present study considers investments in training of older workers, by the public and private sectors, of great importance.

The results of this study indicate the potential of individual training focused on the needs, interests, difficulties and abilities of each participant. As final products, in addition to the design of a training program, didactic materials were developed, containing the step-by-step of the use of each TD and ICT covered in the training.

Among the limitations of this research is the composition of the sample by participants with high levels of education and high family income, which may be considered a possible bias, and the results are targeted only to this specific population. In future studies, a training for the use of technologies that address an individual program rather groups of workers with similar difficulties is suggested, in order to compare and even complement the results of the present research. Another suggestion is the application of the study to other population segments (with different levels of education and income, for instance).

Finally, the training and the high frequency of the use of technologies appear as facilitators for the engagement in labor activities and for the incorporation of such technologies in the routine of older workers. The understanding of how individuals deal with new technologies, the challenges imposed by them and the variables that influence their use are the basis for the elaboration of training programs, since it is necessary to think about strategies aimed at TD and ICT learning for older workers to achieve personal and professional fulfillment.

\section{References}

Abbad, G. S. (1999). Um modelo integrado de avaliação do impacto do treinamento no trabalho - IMPACT. Tese de doutorado, Universidade de Brasília,
Brasília, Brasil.

Abbad, G. S., Pilati, R., Borges-Andrade, J. E., \& Sallorenzo, L. H. (2009). Impacto do treinamento no trabalho - medida em amplitude. In G. S. Abbad, L. 
Mourão, P. P. M. Meneses, T. Zerbini, J. E. BorgesAndrde, J., \& R. Vilas-Boas. Medidas de avaliação em treinamento, desenvolvimento e educação: ferramentas para gestão de pessoas. (pp. 145-162). Porto Alegre: Artmed.

Allen, J., \& De Grip, A. (2012). Does skill obsolescence increase the risk of employment loss? Applied Economics, 44(25), 3237-3245. https://doi.org/10.1080 /00036846.2011.570727

Alley, D. \& Crimmins, E. (2007) The demography of aging and work. In K. S Shultz \& G. A. Adams. Aging and work in the 21st Century (pp. 7-24). Mahwah: Lawrence Erlbaum associates.

Alpass, F., \& Mortimer R. (2007). Ageing workforces and ageing Occupations: a discussion paper. New Zealand: Department of Labour research visit.

American Occupational Therapy Association. (2014). Occupational therapy practice framework: Domain and process (3rd ed.). American Journal of Occupational Therapy, 68(Suppl.1), S1-S48. https://doi.org/10.5014/ajot.2014.682006

Bal, P. M., Kooij, D. T. A. M., \& Rousseau, D. M. (2015). Aging Workers and the Employee-Employer Relationship. London: Springer Publishers.

Beier, M. E. (2015) The aging of workforce and the demands of work in the 21st century. In L. M. Finkelstein, D. M. Truxillo, F. Fraccaroli, \& R. Kanfer. Facing the challenges of multi-age workforce: a use-inspired approach (pp. 108-133). New York and London: Routledge.

Beier, M. E., \& Ackerman, P. L. (2005). Age, ability, and the role of prior knowledge on the acquisition of new domain knowledge: promising results in a real-world learning environment. Psychology and Aging, 20(2), 341-355. https://doi.org/10.1037/08827974.20 .2 .341

Bertolucci, P. H., Brucki, S. M., Campacci, S. R., \& Juliano, Y. (1994). The Mini-Mental State Examination in a general population: impact of educational status. Arquivos de Neuropsiquiatria, 52(1), 1-7.

Boulton-Lewis, G. M. (2010). Education and learning for the elderly: Why, how and what. Educational Gerontology, 36(3), 213-228. https://doi. org/10.1080/03601270903182877

Cai, Z., Fan, X., \& Du, J. (2017). Gender and attitudes toward technology use: a meta-analysis. Computers and Education, 105, 1-13. https://doi.org/10.1016/j. compedu.2016.11.003

Callahan, J., Kiker, D., \& Cross, T. (2003). Does method matter? A meta-analysis of the effects of training method on older learner training performance. Journal of Management, 29(5), 663-680. https:// doi.org/10.1016/S0149-2063(03)00029-1

Camarano, A. A. Perspectivas de crescimento da população brasileira e algumas implicações. (2014). In Camarano, A. A. Novo regime demográfico: uma nova relação entre população e desenvolvimento? (177-210). Rio de Janeiro: IPEA.

Camarano, A. A., Kanso S., \& Fernandes D. (2013). Envelhecimento populacional, perda da capacidade laborativa e políticas públicas brasileiras entre 1992 e 2011. IPEA: 1980. Retrieved from http:// www.ipea.gov.br/portal/index.php?option =com content\&view=article\&id=20491.
Carmichael, F., \& Ercolani, M. G. (2014). Age-training gaps in the European Union. Ageing and Society, 34(1), 129-156. https://doi.org/10.1016/j. jeoa.2015.04.002

Chang, D. F., \& Lin, S. P. (2011). Motivation to learn among older adults in Taiwan. Educational Gerontology, 37(7), 574-592. https://doi. org/10.1080/03601271003715962

Charness, N., \& Czaja, S. J. (2006). Older worker training: what we know and don't know. AARP Public Police Institute, 22, 1-28. Retrieved from http://assets.aarp.org/rgcenter/econ/2006_22_worker.pdf

Chiu, C. J., Hu, Y. H., Lin, D. C., Chang, F. Y., Chang, C. S., \& Lai, C. F. (2016). The attitudes, impact, and learning needs of older adults using apps on touchscreen mobile devices. Computers in $\mathrm{Hu}$ man Behavior archive, 63(C), 189-197. https://doi. org/10.1016/j.chb.2016.05.020

Choi, N. G., \& Dinitto, D. M. (2013). Internet use among older adults: association with health needs, psychological capital, and social capital. Journal of Medical Internet Research, 15(5), 1-16. https://doi. org/10.2196/jmir.2333

Czaja, S. J., \& Sharit, J. (2012). Designing training and instructional programs for older adults. Boca Raton: CRC Press, 2012.

Czaja, S. J, Sharit, J., Charness, N., \& Schmidt, A. C. (2015). The implications of changes in job demands for the continued and future employment of older workers. In L. M. Finkelstein, D. M. Truxillo, F. Fraccaroli, \& R. Kanfer. Facing the challenges of multi-age workforce: a use-inspired approach (pp. 159-179). New York and London: Routledge.

Czaja, S. J., Charness, N., Dijkstra, K., Fisk, A. D., Rogers, W. A, \& Sharit, J. (2006). Computer and technology experience questionnaire. CREATE: technical report, v. 3. Retrieved from http://create-center.gatech.edu/publications_db/report $\% 20$ 3\%20ver1.3.pdf.

European Centre for the Development of Vocational Training. (2012). Working and ageing: the benefits of investing in an ageing workforce. Luxembourg: Publications Office of the European Union.

Finkelstein, L. M., Truxillo, D. M., Fracarolli, F., \& Kanfer, R. (2015). An introduction to facing the challenges of a multi-age workforce: a use-inspired approach. In L. M. Finkelstein, D. M. Truxillo, F. Fraccaroli, \& R. Kanfer. Facing the challenges of multi-age workforce: a use-inspired approach (pp. 3-22). New York and London: Routledge.

Folstein, M. F., Folstein, S. E., \& McHugh, P. R. (1975). Mini Mental State: A practical method for grading the cognitive state of patients for the clinician. Journal of Psychiatric Research, 12(3), 189-198. https:// doi.org/10.1016/0022-3956(75)90026-6

Friemel, T. N. (2014). The digital divide has grown old: determinants of a digital divide among seniors. Chicago: New Media and Society. Retrieved from http://journals.sagepub.com/doi/ abs/10.1177/1461444814538648.

Huber, L., \& Watson, C. (2014). Technology: Education and training needs of older adults. Educational Gerontology, 40(1), 16-25. https://doi.org/10.1080/ 03601277.2013 .768064 
Ilmarinen, J., \& Ilmarinen, V. (2015). Work ability and aging. In L. M. Finkelstein, D. M. Truxillo, F. Fraccaroli, \& R. Kanfer. Facing the challenges of multi-age workforce: a use-inspired approach (pp. 134-156). New York and London: Routledge.

Kooij, D. T. A. M., \& Zacher, H. (2016). Why and when do learning goal orientation and attitude decrease with aging? the role of perceived remaining time and work centrality. Journal of Social Issues, 72(1), 146-168. https://doi.org/10.1111/josi.1216

Laganà, L., Oliver, T., Ainsworth, A., \& Edwards, M. (2011). Enhancing computer self-efficacy and attitudes in multi-ethnic older adults: a randomized controlled study. Ageing and Society, 31(6), 911-933. https://doi.org/10.1017/S0144686X10001340

Lancman, S., Jardim, T., \& Barros, J. O. (2013). Trabalho e subjetividade. In A.P Simonelli, \& D.S. Rodrigues. Saúde e trabalho em debate: velhas questões, novas perspectivas. (pp. 17-31). Brasília: Paralelo 15.

Law, M., Baptiste, S., \& Mills, J. (1995). Client-centred practice: what does it mean and does it make a difference? Canadian Journal of Occupational Therapy, 62(5), 250-257. https://doi.org/10.1177/0008417 49506200504.4

Lee, C. C., Czaja, S. J., \& Sharit, J. (2009). Training older workers for technology-based employment. Educational Gerontology, 35(1), 15-31. https://doi. org/10.1080/03601270802300091

Leppel, K., Brucker, E., \& Cochran, J. (2012). The importance of job training to job satisfaction o folder workers. Journal of Aging and Social Policy, 24(1), 62-76. https://doi.org/10.1080/08959420.2012.629136

Nardi, H. C. (2006). Ética, trabalho e subjetividade: trajetórias de vida no contexto do capitalismo contemporâneo. Porto Alegre: UFRGS.

Nicoll, L. H. (2003). Teaching an old dog new tricks. Computers in Nursing, 21(2), 59-60.

Noe, R. A. (2010). Employee training and development. Boston: McGraw-Hill.

Ogata, K. (2012). Relationship between age-related decline of cognitive functions and willingness to work using a computer. Procedia Computer Science, 8, 255-260. https://doi.org/10.1016/j. procs.2012.01.054

Ono, H., \& Zavodny, M. (2007). Digital inequality: a five-country comparison using microdata. Social Science Research, 36(3), 1135-1155. https://doi. org/10.1016/j.ssresearch.2006.09.001

Organization for economic co-operation and development. (2006). Annual Report. Paris: OECD Publication. Retrieved from https://www.oecd.org/newsroom/36511265.pdf.

Pilati, R., \& Abbad, G. D. S. (2005). Análise fatorial confirmatória da escala de impacto do treinamento no trabalho. Psicologia: teoria e pesquisa, 21(1), 43-51. https://doi.org/10.1590/ S0102-37722005000100007

Ravichandran, S., Cichyb, K. E., Powers, M., \& Kirby, K. (2015). Exploring the training needs of older workers in the food service industry. International Journal of Hospitality Management, 44, 157-164. https://doi.org/10.1016/j.ijhm.2014.10.003

Sharit, J., Czaja, S.J., Hernandez, M.A, \& Nair, S.N. (2009). The Employability of Older Workers as Teleworkers: an appraisal of issues and an empirical study. Human factors and ergonomics in manufacturing, 19(5), 457-477. https://doi.org/10.1002/ hfm. 20138

Smith, E., Smith, A., \& Smith, C. S. (2010). Old dogs, new tricks: training mature-aged manufacturing workers. Journal of Workplace Learning, 22(5), 277291. https://doi.org/10.1108/13665621011053190

Souza, A. C., \& Melo, C. V. B. (2017). O mercado de trabalho brasileiro diante das perspectivas de envelhecimento da população. In Câmara dos Deputados, Centro de Estudos e Debates Estratégicos - Consultoria Legislativa. Brasil 2050: desafios de uma nação que envelhece (pp. 19-42). Brasília: Câmara dos Deputados, Edições Câmara. Retrieved from http://bd.camara.gov.br/bd/handle/bdcama$\mathrm{ra} / 31619$

Sumsion, T., \& Smyth, G. (2001). Barriers to clientcentredness and their resolution. Canadian Journal of Occupational Therapy, 67(1), 15-21. https://doi. org/10.1177/000841740006700104

Sznelwar, L. I., Uchida, S., \& Lancman, S. (2011). A subjetividade no trabalho em questão. Tempo Social, 23(1), 11-30. https://doi.org/10.1590/S010320702011000100002

Tomporowski, P. D. (2003). The psychology of skill: a lifespan approach. Westport: Praeger Publishers.

Tuominen, E., \& Takala, M. (2006). Ageing workforce and employer's attitudes to employment of older persons: the case of Finland. Finnish Centre for Pensions: Working Papers, 5, 1-35, 2006. Retrieved from https://www.julkari.fi/bitstream/ handle/10024/129141/AgeingWorkforceandEmployersAttitudestoEmploymentofOIderPersonsTheCaseofFinland.pdf?sequence $=1$.

Turek, K., \& Perek-Bialas, J. (2013). The role of employer's opinions about skills and productivity of older workers: example of Poland. Employee Relations, 35(6), 648-664. https://doi.org/10.1108/ER-042013-0039

Umemuro, H. (2002). Japanese elderly and computers in the workplace (Keynote Address). Gerontechnology, 2(1), 63-67. https://doi.org/10.4017/ gt.2002.02.01.008.00

Van Deursen, A. J. A. M., \& Van Dijk, J. A. G. M. (2011). Internet skills and the digital divide. New Media and Society, 13(6), 893-911. https://doi. org/10.1177/1461444810386774

Van Rooij, S. W. (2012). Training older workers: lessons learned, unlearned, and relearned from the field of instructional design. Human Resource Management, 51(2), 281-298. https://doi.org/10.1002/ hrm.21466

Vaz, D., Jubilini, L., \& Queiroz, L. (2017). Prática centrada no cliente na reabilitação: definição, instrumentos e desafios. Revista De Terapia Ocupacional da Universidade de São Paulo, 28(1), 122-127. https:// doi.org/10.11606/issn.2238-6149.v28i1p122-127 